\title{
Regional Government Sinergities in the Establishment of Indigenous Villages in Kuantan Singingi District Riau Province
}

\author{
Raja Muhammad Amin ${ }^{1}$, Rury Febrina ${ }^{2}$ \\ \{rury_febrina@yahoo.com ${ }^{1}$ \} \\ Universitas Riau $^{1,2}$
}

\begin{abstract}
Rokan Hulu Regency Government has issued a Regulation Rokan Hulu Regency Number 1 Year 2015 concerning the Establishment of Villages and Traditional Villages. Rohul Regency has designated as many as 89 villages to become traditional villages in the region. But until now no one has received registration and custom village codes from the Ministry of Home Affairs so that the implementation of the established Indigenous Village government still uses the usual village code. This is what underlies the importance of examining the synergy of local government in the formation of Indigenous Villages where the meaning of the formation here is not only up to the establishment of IndigenousVillage but to the implementation of government activities, institutions and communities of the Traditional Village. Efforts to evaluate and accelerate the formation of Indigenous Villages were carried out after the determination by involving not only internal stakeholders but also external, including the provincial government through the Community and Village Empowerment Service of Riau Province and LAM of Riau Province.
\end{abstract}

Keywords: Synergy, Indigenous Villages, Communication and Coordination

\section{Introduction}

Nature of traditional villages is basically a legacy of local community governance organizations, as described in the explanation in Law Number 6 of 2004 concerning Villages, namely: "The indigenousvillage in principle is a local community governance organization that has been preserved from generation to generation which is still recognized and championed by traditional village leaders and communities in order to function to develop local welfare and cultural identity. Customary villages have the village's origin rights since the traditional village was born as an indigenous community in the middle of the community.

Regulated in Law No. 6 of 2004 concerning Villages is a customary law community unit which is a combination of genealogical and territorial. in this regard, the State recognizes and respects the legal community unit and its traditional rights as long as they are alive and in accordance with the development of society and the principles of the Unitary Republic of Indonesia (NKRI).

In Riau Province, which has strong characteristics related to Malay culture, the name indigenous village varies, as is the leadership of the leader, 'Kebatinan' is led by Batin, the State is led by the Head of State and the Traditional Village is led by 'Penghulu' [1]. Attempts 
at uniform in the beginning caused a lot of opposition and made the village become independent. With recognition based on origin, it is able to restore the independence of the village in the administration of government, general development and development of custom, community and community empowerment that is more systemic, integrated, effective and effective [2], [3].

Since Law 6 of 2014 concerning Villages was ratified on January 15, 2014, the central government has given all regencies / cities in Indonesia a year to form traditional villages. This provision is clearly stated in the law, namely article 116 paragraph (3). "Determination of Villages and Traditional Villages for a maximum of 1 (one) year since this Law is enacted". Based on the above provisions, the central government through the Ministry of Home Affairs has given a deadline for the submission of traditional villages until 15 January 2015. However, only two districts succeeded in implementing indigenous Village, Siak District and Rokan Hulu Regency.

The Siak Regency Government welcomed the opportunity by issuing the Siak Regency Regional Regulation No. 2 of 2015 concerning the Stipulation of Indigenous Villages in Siak Regency and the Rokan Hulu Regency Government issued Rokan Hulu District Regulation Number 1 of 2015 concerning the Establishment of Villages and Traditional Villages. What is interesting here is that Siak Regency only stipulates 10 villages to become traditional villages, while Rohul regency determines as many as 89 villages to become traditional villages in the region. But until now no one has received registration and custom village codes from the Ministry of Home Affairs so that the implementation of the established indigenousVillage government still uses the usual village code.

At present the Rokan Hulu Regency government is evaluating the previously established Indigenous Village policy by involving many elements from the government, LAM regency, and traditional / community leaders as well as the provincial government through the Community and Village Empowerment Service and the Ministry of the Interior. This is what underlies the importance of examining the synergy of local government in the formation of Indigenous Villages where the meaning of the formation here is not only up to the establishment of indigenous Village but to the implementation of government activities, institutions and communities of the Traditional Village.

\subsection{Synergy}

Collaboration is a form of cooperation, interaction, compromise of several elements that are related to individuals, institutions and or parties involved directly and indirectly who receive the consequences and benefits. The values that underlie a collaboration are the same goal, common perception, willingness to process, mutual benefit, honesty, compassion and community-based [4] .

The synergy defined by Gerhard Benecke, is; "As the interaction of two or more intellectual capital resources from previously sovereign organizations, which enhances the combined effect of the value creation and competitive performance, which effect is the sum of the individual effects Argenti cited by Gerhard Benecke also says that; "Defines synergy as the concept that the combination of two or more different businesses, activities, or processes will create an overall value that is greater than the sum of the individual parts".

"The definition of synergy as the interaction of two or more sources of intellectual capital from previously sovereign organizations, which increases the combined effect of creating competitive values and performance, whose effects are greater than the number of individual effects" [5].

Based on the above categorization is defined as follows; business units need to work together with each other, communicate for synergies, potential negative impacts of synergy, 
rewards for synergy, history of compartmentalization, potential new synergy initiatives, current synergy initiatives, leadership towards synergy, key obstacles to achieving synergy and need for cultural change

Synergy comes from the word synergy. According to the Big Indonesian Dictionary, synergy means joint activities or operations. Meanwhile, according to Covey quoted by Sri Najiyati, it means synergy as : "Combination or combination of elements or parts that can produce better and bigger output than done individually, besides that a combination of several elements will produce a superior product. Therefore, synergy in development means the integration of various elements of development that can produce better and greater output. Covey added that synergy would be easy to happen if the existing components were able to think of synergy, shared views and mutual respect" [5].

The existence of interaction between the three stakeholders, besides that, there is a need for synergy between the three stakeholders. Najiyati and Rahmat, define synergy as a combination or combination of elements or parts that can produce better and greater output. So synergy can be understood as a joint operation or a combination of elements to produce better output.

Moekijat, who was quoted by Rahmawati, said there were 9 (nine) conditions for achieving effective coordination, namely

1. Direct relationship, that coordination can be more easily achieved through direct personal relationships.

2. Initial opportunity, Coordination can be achieved more easily in the initial levels of planning and policy making.

3. Continuity, Coordination is a continuous process and must take place at all times starting from the planning stage.

4. Dynamism, coordination must be continually changed considering changes in the environment both internally and externally.

5. Clear objectives, clear objectives are important to obtain effective coordination.

6. Simple organization. A simple organizational structure facilitates effective coordination.

7. Clear formulation of authority and responsibility, clear authority not only reduces conflict between different employees, but also helps them in work with a united goal.

8. Effective communication, effective communication is one of the requirements for good coordination.

9. Effective supervision leadership, effective leadership ensures the coordination of the activities of people, both at the planning level and at the level.

Through the elaboration above it can be concluded that synergy can be interpreted as a joint activity or collaboration in order to get maximum results by being connected by several roles. different but related in it. Therefore all components of society and government are expected to work together so that the formation of traditional villages that not only change status but also undergo significant changes from the village administration system, to the order of community life in accordance with the rights of the origin of the traditional village. 


\section{Methodology}

This research is a qualitative research according to Denzin and Lincoln in Lexy J. Moleongnamely research that uses natural settings, with the intention of interpreting phenomena that occur and is done by involving existing methods. Data collection techniques used in this study using the following methods [6]:

a. In-depth interviews, this technique aims to obtain detailed information about research problems.

b. Document search, this method is used to complete data from the first party, namely from research informants so that authentic data and facts are obtained in this study.

\section{Result and Discussion}

Determination of Indigenous Villages is regulated in Government Regulation Number 43 of 2014 as a derivative to implement Law Number 6 of 2014 concerning Villages regulating the mechanism of a Village / Village to be designated as indigenousVillage, which is set forth in Article 30 and 31 paragraph ( 2), the Minister of Home Affairs Regulation No. 52 of 2014 concerning Guidelines for the Recognition and Protection of Indigenous Laws is issued to facilitate regions in conducting studies and identification of the origin rights as the basis for establishing Indigenous Villages.

In the initial stage, it was agreed that the committee structure for the determination of the Rokan Hulu Regency traditional village from the elements of the Rohul Regency Government, LAM Rohul, and academics. Then the team / committee agrees to the requirements indicators that refer to the requirements set out in the Village Law, the purpose of which the indicator is formed or formulated is to facilitate the District / City Regional Governments in Riau Province to identify, assess and assess which village / sub district only the potential and feasibility to be established as an indigenous Village, which results from the identification and assessment of the Village / Village then formulated into the Regional Regulation Draft (Ranperda) to be established for the first time to become indigenous Village and then discussed with the Regional People's Legislative Assembly (DPRD) so that it becomes a Local Regulation (Perda) concerning the establishment of Indigenous Villages

After the Indigenous Village Determination Committee of Rokan Hulu Regency is formed, and also the indicators of the requirements of a Village can be established as indigenousVillagehave been formulated, the stages of indigenousVillage are determined. The mechanism for determining Indigenous Villages that must be carried out by the Indigenous Village Determination Committee of Rokan Hulu Regency is as follows:

1. District / City Government conducts an inventory of villages that have obtained the village code.

2. Identification and assessment of existing villages, which can be determined as indigenous village.

3. The results of the identification and assessment of the Village that will be designated as indigenousVillage are then poured into the Regional Regulation Draft (Ranperda) to determine the Customary Village. 
4. The Regional Regulation Draft (Ranperda) concerning the stipulation of Traditional Villages, is then discussed with the Regency / City DPRD.

Coordination and dissemination of the Determination of Indigenous Villages aims to collect and facilitate the work of the Rokan Hulu District Indigenous Village Determination Committee to identify villages that have the potential to be designated as indigenous Village, because considering the time is quite short to carry out the process of identifying and assessing each each village. The identification results are then formulated into the Draft Regional Regulation concerning the determination of Traditional Villages by containing 21 (twenty one) Villages that are entitled "very feasible and feasible" to be designated as indigenous Village, the Draft Regional Regulation concerning the Establishment of Indigenous Villages is also included with the Academic Manuscript submitted by the Rokan Hulu Malay Customary Institution together with the Rokan Hulu Village Community Empowerment Agency using experts (Academics). Then the ratification of the Regional Regulation concerning the establishment of indigenous Village on January 19, 2015.

If examined in the scope of Riau Province, only Siak and Rokan Hulu Regencies succeeded in establishing indigenous Village in accordance with the deadline required in the Village Law Article 116 paragraph 3. The dynamics that occur are not only in the District / City but also in the Provincial Government specifically to follow up on the determination of the Traditional Village by the Regency / City Government. The Riau Provincial Government through the DPMD assesses that no Indigenous Village has been formed in Riau Province, considering the two Regencies that succeeded in establishing indigenous Village in their area at the last deadline required in the Village Law, still they do not meet administrative requirements especially related to regional boundaries.

In addition there is an emphasis on community initiatives as one of the main elements in the prerequisite for establishing indigenous Villages. With the issuance of Permendagri No. 1 of 2017 concerning Village Arrangement, there are several scope of this regulation including village arrangement and arrangement of traditional villages. Village arrangement in the form of the formation of traditional villages and villages, elimination of villages and traditional villages, and changes in the status of villages and traditional villages. This regulation explains that the arrangement of traditional villages can be carried out by the Central Government, Provincial Governments and Regency / City Governments. The establishment of the Village was in effect mutatis mutandis against the formation of the indigenous Village by the Government above both related to the formation of the indigenous Village, and the change in the status of the indigenousVillage. Based on Permendagri No. 1 of 2017 emphasizes that the Provincial Regulation becomes a guideline for District / City Regional Governments in setting District / City Regulations that govern the administration of Indigenous Villages, the implementation of customary village development, community development of Indigenous Villages and community empowerment of indigenous Village.

The latest regulation of the Minister of Home Affairs is considered excessive in the regulation of the indigenous Village considering that the provincial government can have the initiative to form indigenous Villages which in other laws and regulations do not regulate this. In addition, the most important thing is the determination of the main criteria / measures for the establishment and formation of indigenous Villages. The role of each party should be well mapped from the initiating party, the party that determines and the party that registers and registers. Village Arrangement as mandated in the Village Law and PP No. 43 of 2015 underlines that indigenous Village is determined by the District / City Government, evaluated by the provincial government and registered by the Ministry of Home Affairs. Based on the 
explanation above, it can be drawn an important point that it is still a big public relations related to the arrangement of the indigenous Village and has an impact on the obscurity of the indigenous Village that has been established by the District / City Government. This also affects the uncertainty of the District / City Government to follow up on the opportunity to form / change the status of the village into an indigenous village so as to extend the vacuum of the formation of the traditional village.

The Provincial Government currently has compiled an Academic Script of the Riau Provincial Ranperda concerning Institutional Arrangements, Filling of Position and Term of Office of Traditional Village Heads, although basically the policy cannot be applied due to the absence of a registered Customary Village. The dualism of views due to the lack of regulation on Indigenous Villages makes the provincial and district / city governments blame each other.

In addition, aspects of coaching to districts / cities that want to change the status of villages to traditional villages in their regions are also carried out by the provincial government through the Community and Village Empowerment Office of Riau Province. In addition, the Riau Provincial Government has also held meetings in the form of workshops on the dissemination of academic texts of the Provincial Draft Local Regulation on Institutional Arrangements, Filling of Position and Term of Office of Traditional Village Heads by inviting LAM District / City and related agencies. However, this policy is structured more generally because each village has different characteristics and mechanisms for the selection of village heads and other institutions. The content in this draft policy discusses the position and territory, the authority of traditional villages, the administration of traditional village governance, the composition of traditional village government, financing, guidance and supervision. In this case the emphasis on the formation / determination / change of the status of the village into a traditional village remains the domain of the Regency / City government. Even though the indigenousVillage was back, the registration code from the Province and the traditional village code from the Ministry of Home Affairs had not yet been.

\section{Conclusion}

Obtained Based on the results of the above discussion, there were several stages in the establishment of indigenous Villages in Rokan Hulu Regency, namely identification and assessment of existing villages. can be determined to be indigenousVillage based on the principle of general requirements and specifically the establishment of indigenous Village. The results of the identification and assessment of the Village that will be designated as indigenous Village are then poured into the Regional Regulation Draft (Ranperda) to determine the Customary Village.

Regional Regulation Draft (Ranperda) concerning the determination of indigenous Villages, then discussed and agreed upon with the Regency / City DPRD. Then the ratification of the Regional Regulation concerning the establishment of indigenous Village on January 19, 2015. At the Provincial Government level in synergy with the Provincial, District / City LAM and several related stakeholders, it has made an assessment and academic draft of the Regional Regulation on institutional arrangements, filling out the information, and the term of office of the head indigenous Village which is mandated in the Village Law Article 109 to anticipate a longer vacuum due to the vacancy in the regulation of Riau Province related to indigenous Village. 


\section{References}

[1] R. M. Amin and R. Febrina, "Strategi Pemberdayaan Masyarakat Melalui Pengembangan Kapasitas Kelembagaan Kampung Adat Di Kabupaten Siak Provinsi Riau," Nakhoda J. Ilmu Pemerintah., vol. 15, no. 26, pp. 65-77, 2016.

[2] M. Thalib, "Implementasi visi riau 2020 pada lembaga adat melayu riau," JIANA (Jurnal Ilmu Adm. Negara), vol. 14, no. 1, pp. 39-45, 2016.

[3] M. Bachtiar, "Peranan Lembaga Adat Melayu Riau Dalam Penyelesaian Konflik Tanah Ulayat di Provinsi Riau," J. Huk. Respublica, vol. 16, no. 2, pp. 298-312, 2017.

[4] N. Haryono, "Network to build public sector collaboration, Airlangga University," $J$. Public Adm. Netw., vol. IV, no. 1, 2012.

[5] S. R. T. S. Najiyati, Sri, "Synergy of Government Agencies in the Development of an Integrated Independent City," J. Transm., vol. 28, 2011.

[6] L. J. Moleong, Qualitative Research Methods; Revised Edition. Bandung: PT Remaja Rosdakarya, 2010. 